Document downloaded from:

http://hdl.handle.net/10251/149938

This paper must be cited as:

Di Prima, S.; Bagarello, V.; Lassabatere, L.; Angulo-Jaramillo, R.; Bautista, I.; Burguet, M.; Cerda, A.... (2017). Comparing Beerkan infiltration tests with rainfall simulation experiments for hydraulic characterization of a sandy-loam soil. Hydrological Processes. 31(20):35203532. https://doi.org/10.1002/hyp.11273

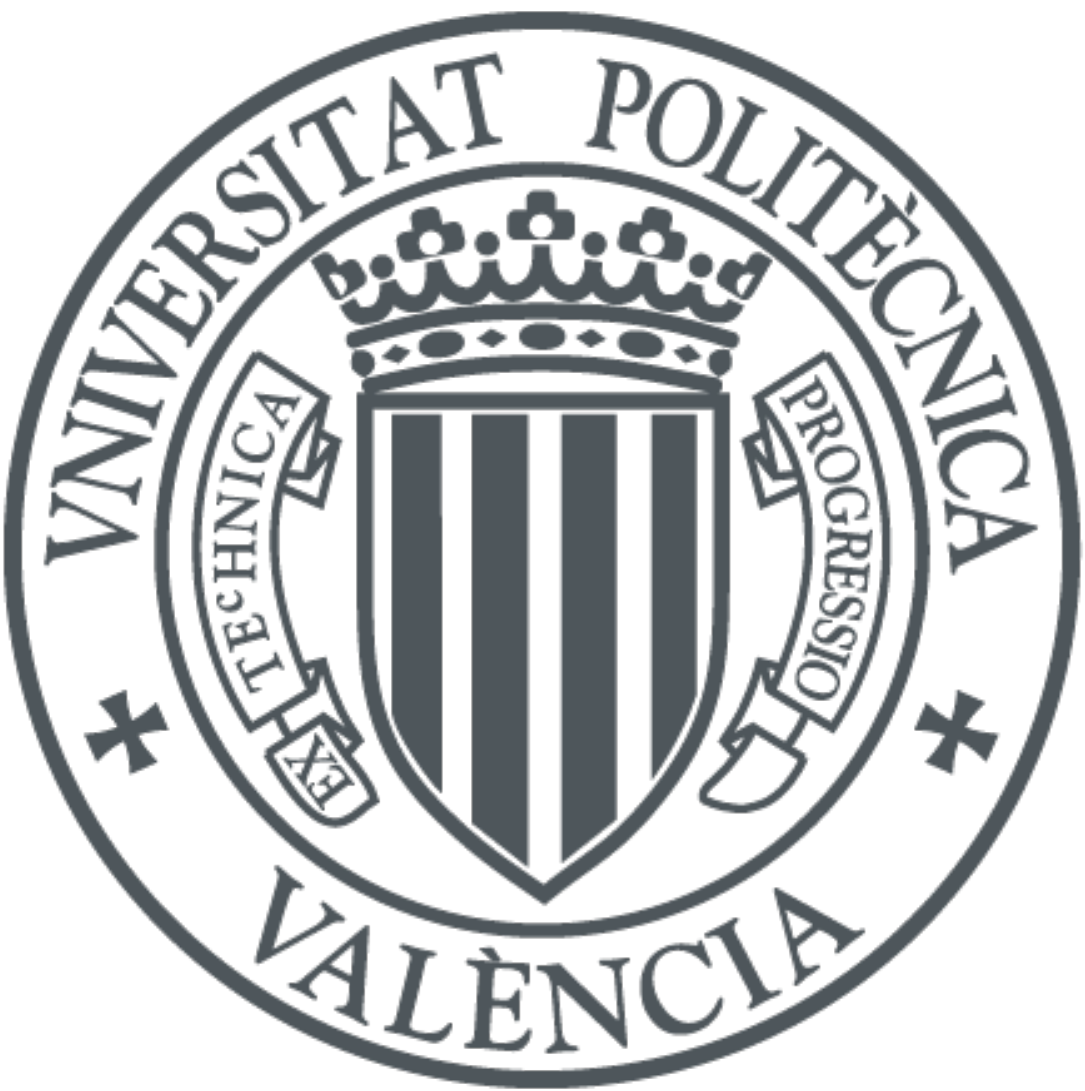

The final publication is available at https://doi.org/10.1002/hyp.11273

Copyright John Wiley \& Sons

Additional Information 


\title{
Comparing Beerkan infiltration tests with rainfall simulation experiments for hydraulic characterization of a sandy-loam soil
}

\author{
S. Di Prima ${ }^{1,2, *}$, V. Bagarello ${ }^{3}$, L. Lassabatere ${ }^{4}$, R. Angulo-Jaramillo ${ }^{4}$, I. Bautista ${ }^{5}$, M. Burguet ${ }^{2}$, A. \\ Cerdà $^{2,6}$, M. Iovino ${ }^{3}$, M. Prosdocimi ${ }^{7}$ \\ ${ }^{1}$ Agricultural Department, University of Sassari, Viale Italia, 39, 07100 Sassari, Italy \\ ${ }^{2}$ Soil Erosion and Degradation Research Group. Department of Geography, University of Valencia, Blasco Ibáñez, 28, 46010 Valencia, Spain \\ ${ }^{3}$ Department of Agricultural, Food and Forest Sciences, University of Palermo, Viale delle Scienze, 90128 Palermo, Italy \\ ${ }^{4}$ Université de Lyon; UMR5023 Ecologie des Hydrosystèmes Naturels et Anthropisés; CNRS ; ENTPE ; Université Lyon 1; 3 rue Maurice Audin, 69518 \\ Vaulx-en-Velin, France \\ ${ }^{5}$ Universitat Politècnica de València, Research Institute of Water and Environmental Engineering - Re-Forest, Valencia, Spain \\ ${ }^{6}$ Soil Physics and Land Management Group, Wageningen University, Droevendaalsesteeg 4, 6708PB Wageningen, The Netherlands. \\ ${ }^{7}$ Department of Land, Environment, Agriculture and Forestry, University of Padova, Agripolis, Viale dell’Università 16, 35020 Legnaro PD, Italy \\ * Corresponding Author. E-mail: sdiprima@uniss.it
}

This is the peer reviewed version of the following article: Di Prima S, Bagarello V, Lassabatere L, Angulo-Jaramillo R, Bautista I, Burguet M, Cerdà A, Iovino M, Prosdocimi M. 2017. Comparing Beerkan infiltration tests with rainfall simulation experiments for hydraulic characterization of a sandy-loam soil. Hydrological Processes. DOI: 10.1002/hyp.11273, which has been published in final form at http://doi.org/10.1002/hyp.11273. This article may be used for non-commercial purposes in accordance with Wiley Terms and Conditions for Self-Archiving.

\begin{abstract}
Saturated soil hydraulic conductivity, $K_{s}$, data collected by ponding infiltrometer methods and usual experimental procedures could be unusable for interpreting field hydrological processes and particularly rainfall infiltration. The $K_{s}$ values determined by an infiltrometer experiment carried out applying water at a relatively large distance from the soil surface could however be more appropriate to explain surface runoff generation phenomena during intense rainfall events. In this study, a link between rainfall simulation and ponding infiltrometer experiments was established for a sandy-loam soil. The height of water pouring for the infiltrometer run was chosen establishing a similarity between the gravitational potential energy of the applied water, $E_{p}$, and the rainfall kinetic energy, $E_{k}$. To test the soundness of this procedure, the soil was sampled with the BEST (Beerkan Estimation of Soil Transfer parameters) procedure of soil hydraulic characterization and two heights of water pouring (0.03 m, i.e. usual procedure, and $0.34 \mathrm{~m}$, yielding $E_{p}=E_{k}$ ). Then, a comparison between experimental steady-state infiltration rates, $i_{s R}$, measured with rainfall simulation experiments determining runoff production and $K_{s}$ values for the two water pouring heights was carried out in order to discriminate between theoretically possible $\left(i_{s R} \geq K_{s}\right)$ and impossible $\left(i_{s R}<K_{s}\right)$ situations. Physically possible $K_{s}$ values were only obtained applying water at a relatively large distance from the soil surface, since $i_{s R}$ was equal to $20.0 \mathrm{~mm} \mathrm{~h}^{-1}$ and $K_{s}$ values were $146.2-163.9$ and $15.2-18.7 \mathrm{~mm} \mathrm{~h}^{-1}$ for a height of water pouring of 0.03 and $0.34 \mathrm{~m}$, respectively. This result suggested the consistency between Beerkan runs with a high height of water pouring and rainfall simulator experiments. Soil compaction and mechanical aggregate breakdown were the most plausible physical mechanisms determining reduction of $K_{s}$ with height. This study demonstrated that the height from which water is poured onto the soil surface is a key parameter in infiltrometer experiments and can be adapted to mimic the effect of high intensity rain on soil hydraulic properties.
\end{abstract}

\section{Keywords}

Saturated soil hydraulic conductivity; Beerkan infiltration; height of water application; rainfall simulation; runoff. 


\section{Introduction}

Determining soil hydraulic properties is necessary for interpreting and simulating many hydrological processes having environmental and economic importance (Turner et al., 2000), such as rainfall partition into infiltration and runoff (Rockström et al., 1998; Cassinari et al., 2015; Iovino et al., 2016). The saturated soil hydraulic conductivity, $K_{s}$, exerts a dominating influence on the partitioning of rainfall in vertical and lateral flow paths. Therefore, estimates of $K_{s}$ are essential for describing and modeling hydrological processes (Zimmermann et al., 2013).

Many methods have been developed over time for determining $K_{s}$ but different methods often yield substantially dissimilar $K_{s}$ values due to the extreme sensitivity of this parameter to sample size, flow geometry, sample collection procedures and various soil physical-hydrological characteristics (Reynolds et al., 2000). Maintaining functional connection of the sampled soil volume with the surrounding soil implies determination of $K_{s}$ directly in the field (Bouma, 1982). In principle, using infiltrometers seems logical in the study of water infiltration processes due to the similarity between the experimental method for soil hydraulic characterization and the hydrological process to be interpreted or modeled. According to several investigations, however, $K_{s}$ data collected by ponding infiltrometer methods could be expected to be unusable for interpreting field hydrological processes, and particularly rainfall partition into infiltration and surface runoff.

For instance, Cerdà (1996) reported an infiltration rate measured by means of ponding experiments eight times higher than the one measured by rainfall simulation experiments. Moreover, $K_{s}$ values precluding occurrence of runoff were measured with the ring infiltrometer by van de Giesen et al. (2000). These authors suggested that massive air inclusion in the soil, crust formation and associated particle sorting phenomena, decreasing overall permeability during the rainstorm, influenced the runoff production. Evidently, these phenomena did not occur or were less noticeable when $K_{s}$ was measured with the ring infiltrometer. For an initially unsaturated clay soil without visible cracks, the median $K_{s}$ values obtained by Bagarello et al. (2010, 2013) with the simplified falling head technique (Bagarello et al., 2004) were of $600 \mathrm{~mm} \mathrm{~h}^{-1}$ or more, notwithstanding that surface runoff was observed at the sampled site and, generally, rainfall intensities did not exceed $100 \mathrm{~mm} \mathrm{~h}^{-1}$. This experimental information suggested that runoff occurrence needs a general reduction of surface soil permeability that can be due to swelling and compaction phenomena induced by long and intense rainfall. In other terms, transformation of rainfall into rainfall excess needs a preliminary modification of the soil because the porous medium in its initial status is not able to produce runoff. This phenomenon was also observed in badland surfaces where pore clogging by sediments and clay swelling resulted in an impermeable surface layer that contributed to runoff, but only after the cracks closure, which was named delayed Hortonian overland flow model (Cerdà, 1999).

In contrast, underestimation of the initial soil infiltrability determined with the double-ring infiltrometer was reported by Liu et al. (2011) in comparison with that obtained by a rainfall simulation experiment. According to these authors, the double-ring infiltrometer method underestimated the initial soil infiltrability due to the rapid destruction of the soil surface aggregates that occurred during the rapid addition of water required by the methodology.

Bagarello et al. (2014a) and Alagna et al. (2016a) suggested that the $K_{s}$ values determined by infiltration experiments carried out applying water at a relatively large distance from the soil surface could be more appropriate to explain surface runoff generation phenomena during intense rainfall events than those obtained by applying water close to the infiltration surface. These authors used the Beerkan Estimation of Soil Transfer parameters (BEST) procedure for complete soil hydraulic characterization 
(Lassabatere et al., 2006) to analyze the field infiltration experiment. An experimental methodology combining low and high heights of water pouring seems appropriate to test the effect of intense and prolonged rainfall events on the hydraulic characteristics of the surface soil layer. In fact, an intense and prolonged rainfall event has a perturbing effect on the soil surface and, reasonably, can better be represented by higher heights of water pouring (Alagna et al., 2016a). Obviously, this methodology is also simpler than an approach involving soil characterization both before and after natural or simulated rainfall since it needs less equipment and field work. However, the methodology using low and high heights of pouring has been applied to a limited number of soils until now and therefore it requires further testing. Mini disk infiltrometers (Decagon, 2014) seem to be ideal devices for testing what happens at the soil surface after a ponding infiltration run since they are simple to use and have been specifically employed for estimating infiltration rates of soil crusts (Li et al., 2005).

Rainfall simulation experiments are more realistic and accurate, but also more sophisticated and costly (Cerdà, 1997). Rainfall simulation is often used to measure the infiltration process (e.g., Tricker, 1979; Bhardwaj and Singh, 1992; Liu et al., 2011; Iserloh et al., 2013a), and it has become an important method for studying soil erosion and other soil hydrological processes (Iserloh et al., 2013a; Lassu et al., 2015; Keesstra et al., 2016), improving our understanding of the role of the rainfall properties and erosivity on soil hydrology (Diodato et al., 2014; Nunes et al., 2016). Rainfall simulation allows a specific and reproducible assessment of the meaning and the impact of several factors on the process of interest, such as slope, soil type, initial soil moisture, splash of raindrops, surface soil structure, vegetation cover and vegetation structure (Bowyer-Bower and Burt, 1989). However, the possibility of establishing a link between rainfall simulation experiments and infiltrometer runs has still to be checked (Alagna et al., 2016a). Another reason for investigating the link between Beerkan and rainfall simulation experiments is that both of them can also be used to determine soil sorptivity (Lassabatere et al., 2006; White et al., 1989), which expresses the soil's ability to rapidly capture water (Shaver et al., 2013).

Establishing the response of sandy-loam soils during rainfall simulation and infiltrometer determination of $S$ and $K_{s}$ appears particularly necessary (Somaratne and Smettem, 1993; Lado et al., 2004). As suggested by Alagna et al. (2016a), a certain rigidity of the porous medium, and hence a reduced sensitivity to disturbance due to wetting, could be expected since the percentage of coarse particles is high in these soils. However, the possibility that water application determines particle detachment and clogging of the largest pores cannot be excluded since the limited clay content also implies weak or relatively weak soil aggregation.

The objectives of this research were to: (i) compare Beerkan infiltration tests with rainfall simulation experiments in terms of infiltration rates and estimates of soil sorptivity, $S$, and saturated hydraulic conductivity, $K_{s}$, (ii) investigate the consistency of the Beerkan experiment with rainfall simulation tests, depending on the height of pouring water, and (iii) relate any discrepancy between methods to potential changes in soil structure related to these methodologies. Indeed, it is expected that Beerkan runs with low heights of water pouring will disturb soil structure less than Beerkan runs with high heights or rainfall simulation experiments. This research presents a methodology that allows the comparison between ring infiltration measurements and rainfall simulation, including related estimates of soil hydraulic properties, for the case of a sandy-loam soil and could be extended to several types of soil.

\section{Materials and methods}

\subsection{Study area}

The study area consists of a 25-year-old vineyard located at El Celler del Roure in Les

Di Prima S, Bagarello V, Lassabatere L, Angulo-Jaramillo R, Bautista I, Burguet M, Cerdà A, Iovino M, Prosdocimi M. 2017. Comparing Beerkan infiltration tests with rainfall simulation experiments for hydraulic characterization of a sandy-loam soil. Hydrological Processes. DOI: 10.1002/hyp.11273 
Alcusses de Moixent, within the Canyoles river watershed in the province of Valencia (La Costera District, eastern Spain) (38 48' 33.12" N, $0^{\circ} 49^{\prime}$ 3.27" O, elevation of $577 \mathrm{~m}$ a.s.l.), about $100 \mathrm{~km}$ from the Mediterranean Sea. Wine making has a long tradition in this area which goes back to 400 $\mathrm{BC}$, such as it has been proved in the nearby Iberian settlement of La Bastida in the municipality of Moixent.

Climate is typically Mediterranean with approximately four months of summer drought (June-September). Mean annual rainfall is 350 $\mathrm{mm}$. Rainfall is distributed in autumn, winter and spring, with maximum peak rainfall intensities during the autumn season, when values higher than $200 \mathrm{~mm}$ day $^{-1}$ were occasionally recorded during the last 50 years (Prosdocimi et al., 2016). Extreme storm events are frequent in this area. Mean annual temperature is about $13.8^{\circ} \mathrm{C}$ and the hottest month (August) has an average temperature of about $23{ }^{\circ} \mathrm{C}$.

The soil (Typic Xerothent according to the Soil Survey Staff, 1998), was classified as sandy-loam according to USDA standards. Its mean depth is $40 \mathrm{~cm}$, with $8 \%$ of rock fragment content, low levels of soil organic matter $(<1 \%)$ due to the millennia of agricultural use and soil disturbance (ploughing) and basic $\mathrm{pH}$ (8) (Prosdocimi et al., 2016).

\subsection{Soil sampling}

On November 2015, a total of 20 undisturbed soil cores ( $5 \mathrm{~cm}$ in height by $5 \mathrm{~cm}$ in diameter) were collected at a depth of the 0 to $5 \mathrm{~cm}$ and 5 to $10 \mathrm{~cm}$ in randomly chosen sampling points, in an area of approximately $150 \mathrm{~m}^{2}$. These cores were used to determine the dry soil bulk density, $\rho_{b}$ (g $\mathrm{cm}^{-3}$ ) and the soil water content at the time of the combined rainfall plus infiltrometer experiments, $\theta_{i}\left(\mathrm{~cm}^{3} \mathrm{~cm}^{-3}\right)$. The soil porosity, $\varepsilon\left(\mathrm{cm}^{3} \mathrm{~cm}^{-3}\right)$, was calculated from the $\rho_{b}$ data, assuming a soil particle density of $2.65 \mathrm{~g} \mathrm{~cm}^{-3}$.

Three disturbed soil samples were also collected from the upper $10 \mathrm{~cm}$ of soil to determine the soil particle size distribution (PSD).
The PSD was determined using conventional methods following $\mathrm{H}_{2} \mathrm{O}_{2}$ pre-treatment to eliminate organic matter and clay deflocculation using sodium hexametaphosphate and mechanical agitation (Gee and Bauder, 1986). Table 1 summarizes the measured soil properties.

Table 1. Clay ( $\mathrm{cl}$ in \%), silt (si in \%), and sand (sa in \%) content (USDA classification system) in the 0-0.1 m depth range, soil textural classification, dry soil bulk density $\left(\rho_{b}\right.$ in $\mathrm{g} \mathrm{cm}^{-3}$ ), soil porosity ( $\varepsilon$ in $\mathrm{cm}^{3} \mathrm{~cm}^{-3}$ ), initial volumetric soil water content $\left(\theta_{i}\right.$ in $\left.\mathrm{cm}^{3} \mathrm{~cm}^{-3}\right)$, and saturated volumetric water content $\left(\theta_{s, w}\right.$ in $\left.\mathrm{cm}^{3} \mathrm{~cm}^{-3}\right)$, for the soil sampled on November 2015. Coefficients of variation (CV in \%) are indicated in brackets.

\begin{tabular}{ll}
\hline variable & Mean \\
\hline$c l$ & $19.3(24.9)$ \\
$s i$ & $13.4(23.0)$ \\
$s a$ & $67.3(6.3)$ \\
Textural classification & Sandy loam \\
$\rho_{b}$ & $1.26(11.1)$ \\
$\varepsilon$ & $0.52(10.1)$ \\
$\theta_{i}$ & $0.14(35.4)$ \\
$\theta_{\mathrm{s}, w}$ & $0.44(11.7)$ \\
\hline
\end{tabular}

\subsection{Rainfall simulation}

A one-nozzle (Hardi-1553-12) rainfall simulator was used to apply water from a 2-m height on a $1 \mathrm{~m}^{2}$ sprinkling area. A detailed description of the rainfall simulator is given in Cerdà (1999) and Iserloh et al. (2013b). Previous investigations reported, for this rainfall simulator, kinetic energy, $E_{k}$, estimates of $390-423 \mathrm{~J} \mathrm{~m}^{-2}$ for a rainfall of duration $1 \mathrm{~h}$ and intensities of 51-55 $\mathrm{mm} \mathrm{h}^{-1}$ (Cerdà et al., 1997; Iserloh et al., 2013a). In this study, ten one-hour storms were simulated at different locations in the sampling area at 55 $\mathrm{mm} \mathrm{h}^{-1}$ rainfall intensity. Storms similar to the one simulated for this experiment have a return period of 4-5 years (Cerdà, 2001). Moreover, rainfall events of $1 \mathrm{~h}$ duration with intensities of 80-110 $\mathrm{mm} \mathrm{h}^{-1}$ are not extraordinary in South 


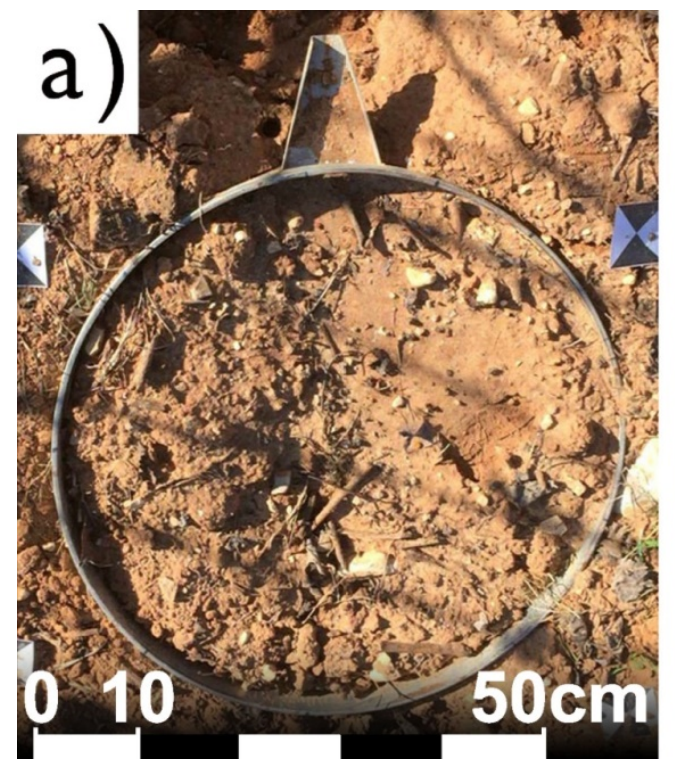

Figure 1. View of the a) $0.56 \mathrm{~m}$ and b)

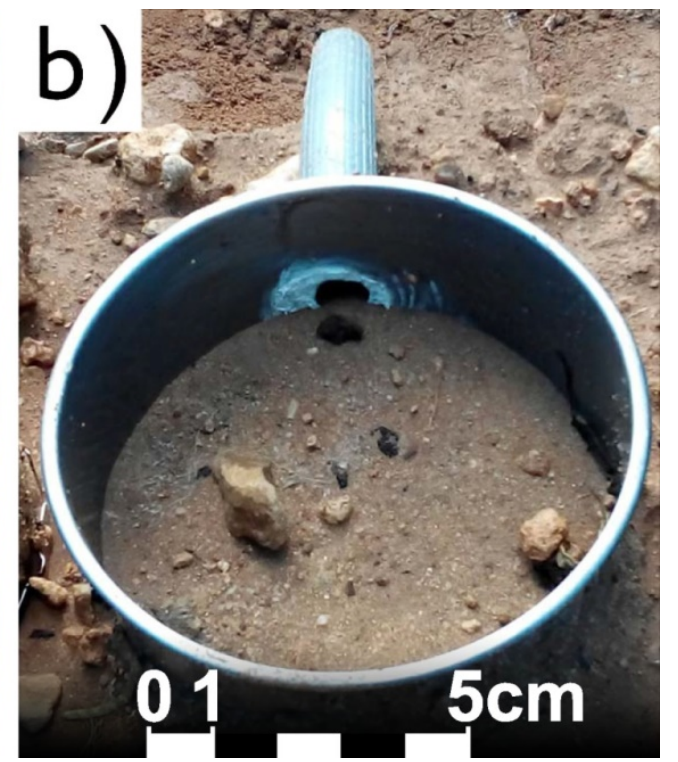

$0.09 \mathrm{~m}$ diameter plots
East Spain and occur on average every 10 years (Castillo and Beltrán, 1979; Cerdà, 2001). The slope $\left(\sim 3^{\circ}\right)$ was considered during the selection of the test areas to ensure that the plots were representative of the site.

Seven experiments were carried out on $0.56 \mathrm{~m}$ diameter plots $\left(0.246 \mathrm{~m}^{2}\right.$ plot area $)$ that were established at the center of the $1 \mathrm{~m}^{2}$ sprinkling area. Infiltration in the $0.754 \mathrm{~m}^{2}$ buffer area around the plot area contributed to limit the lateral capillary effects at the ring edge thus determining a near one-dimensional infiltration process. The other three tests were carried out on nine smaller plots, i.e. three plots for each simulated storm, each having a diameter of $0.09 \mathrm{~m}\left(6.4 \times 10^{-3} \mathrm{~m}^{2}\right.$ plot area; $0.98 \mathrm{~m}^{2}$ buffer area). Each plot had a drain pipe in order to collect the runoff at the outlet (Fig. 1). The large plot experiment was carried out taking into account that rainfall kinetic energy was known for a particular intensity value (equal or close to $55 \mathrm{~mm} \mathrm{~h}^{-1}$ ) and a spatially variable simulated rainfall was expected (Cerdà et al., 1997; Iserloh et al., 2013a). Consequently, the large plot experiment was planned under the expectation that the sampled plot received water at a mean intensity equal to $55 \mathrm{~mm} \mathrm{~h}^{-1}$. However, as explained below, the ponding infiltrometer runs were carried out by using relatively small cylinders, following a procedure successfully tested by Bagarello et al. (2014a) and Alagna et al. (2016a). Therefore, the small plot experiment was carried out to be sure that the data collected on the larger plots were also representative at a smaller scale, given that infiltration data collected in the field can depend on the size of the individually sampled area (e.g., Youngs, 1987; Bagarello et al., 2013).

Surface runoff from the sampled plot was collected at 1 min intervals during each simulated rainfall event from the moment at which the runoff started to run out of the outlet until it ceased. Then, the infiltration curves were drawn by subtracting the runoff rates from the rainfall intensity (Cerdà, 1998). The data obtained from each run included: i) time to ponding, $t_{p}(\mathrm{~s})$, as the time from the beginning of the rainfall simulation until the development of ponds on approximately $40 \%$ of the total plot surface (Cerdà and Doerr, 2007); ii) time to runoff, $t_{r}(\mathrm{~s})$, as the time from the beginning of the rainfall simulation until the beginning of runoff; iii) runoff coefficient, $R_{c}$, as the percentage of rainfall that became surface runoff and iv) experimental steady-state infiltration rate, $i_{S R}\left(\mathrm{~mm} \mathrm{~h}^{-1}\right)$, estimated considering the last data points of the infiltration curve, describing the steady-state phase of the process.

Di Prima S, Bagarello V, Lassabatere L, Angulo-Jaramillo R, Bautista I, Burguet M, Cerdà A, Iovino M, Prosdocimi M. 2017. Comparing Beerkan infiltration tests with rainfall simulation experiments for hydraulic characterization of a sandy-loam soil. Hydrological Processes. DOI: 10.1002/hyp.11273 


\subsection{Ponding infiltrometer runs}

A small diameter (i.e. $0.085 \mathrm{~m}$ ) ring inserted to a depth of $0.01 \mathrm{~m}$ was used for the infiltrometer runs (Lassabatere et al., 2006). According to Bagarello et al. (2014a), a relatively small diameter of the ring was chosen to detect more clearly potential effects of soil disturbance due to water. A total of 20 runs were carried out in November 2015 at randomly selected locations of the sampling site. For each run, a number of water volumes, $N_{v}=15$, each of $48 \mathrm{~cm}^{3}$, were successively poured on the confined infiltration surface.

Ten runs were carried out by pouring water at a small height above soil surface, i.e. at a height, $h_{w}$, of $0.03 \mathrm{~m}$ (low, L, runs). The energy was dissipated with the hand fingers, in an attempt to minimize soil disturbance due to water application, as commonly suggested (Reynolds, 1993). Water was applied from $h_{w}=0.34 \mathrm{~m}$ at the other 10 sampling points (high, $\mathrm{H}$, runs). In this case, the soil surface was not shielded to maximize possible damaging effects of water impact. To ensure flow verticality and prevent wind effects, a transparent pipe was used. A height of $0.34 \mathrm{~m}$ was chosen in order to perform a run characterized by a gravitational potential energy, $E_{p}$, comparable to the $E_{k}$ value of the simulated rainfall. Each water application generally contributes to alter the soil surface and the total energy of the applied water was found to be an appropriate predictor of the expected changes in $K_{s}$ for another sandy-loam soil (Bagarello et al., 2014a). Also, models of transient soil surface sealing and infiltration establish that, for a given soil, the final saturated conductivity depends on the cumulative energy of the applied water (e.g., Brakensiek and Rawls, 1983; Shainberg and Singer, 1988; Mualem et al., 1990; King and Bjorneberg, 2012). In this study, taking into account that both the mass of water and the height of fall were known, the $\mathrm{L}$ and $\mathrm{H}$ runs were characterized by $E_{p}$ values of 37 and $423 \mathrm{~J} \mathrm{~m}^{-2}$ respectively. To be clearer, these values were obtained as $m \times g \times h / \sigma$, in which $m$ is the mass of the applied water $(0.72 \mathrm{~kg}), g$ is the acceleration due to gravity $\left(9.81 \mathrm{~m} \mathrm{~s}^{-2}\right), h$ is the height of fall $(0.03$ or $0.34 \mathrm{~m})$ and $\sigma$ is the infiltration surface $\left(5.67 \times 10^{-3} \mathrm{~m}^{2}\right)$. Collision of raindrops on a bare soil surface results in mechanical changes of the exposed soil, expressed in terms of compaction, particle detachment, and splash. Therefore, an $\mathrm{H}$ run characterized by a gravitational potential energy equal to the kinetic energy of the simulated rainfall was expected to be the best choice for a comparison between the two methods.

For a given water volume, the time needed for the water to infiltrate was logged, and the mean cumulative infiltration time of the applied volumes was calculated for both the $\mathrm{L}, \Delta t_{L}(\mathrm{~s})$, and the $\mathrm{H}, \Delta t_{H}(\mathrm{~s})$, runs. These calculations were made since, for a given amount of applied water, run duration is inversely related to infiltration rate (Alagna et al., 2016a).

Another measurement campaign, including seven $\mathrm{L}$ runs and seven $\mathrm{H}$ runs at randomly selected locations, was conducted at the same field site on May 2016 in conjunction with minidisk infiltrometer runs (see sub-section 2.5).

For each infiltration run, cumulative infiltration, $I(\mathrm{~mm})$, was plotted against time, $t(\mathrm{~s})$, and a linear regression line was fitted to the last data points, describing the near steady-state conditions, in order to estimate the experimental steady-state infiltration rate, $i_{S P}\left(\mathrm{~mm} \mathrm{~h}^{-1}\right)$, and the associated intercept, $b_{s}(\mathrm{~mm})$. The BEST-steady algorithm (Bagarello et al., 2014b) was then applied to estimate the soil sorptivity, $S$ ( $\mathrm{mm} \mathrm{h}^{-}$ 0.5 ), and the saturated soil hydraulic conductivity, $K_{s}\left(\mathrm{~mm} \mathrm{~h}^{-1}\right)$, by the following equations (Di Prima et al., 2016):

$$
\begin{aligned}
& S=\sqrt{\frac{i_{s P}}{A+\frac{C}{b_{s}}}} \\
& K_{s}=\frac{C i_{s P}}{A b_{s}+C}
\end{aligned}
$$

where the $A\left(\mathrm{~mm}^{-1}\right)$ and $C$ constants are defined for the specific case of the Brooks and Corey 
(1964) relation and taking into account initial conditions as follows (Haverkamp et al., 1994):

$$
\begin{aligned}
& A=\frac{\gamma}{r_{d}\left(\theta_{s}-\theta_{i}\right)} \\
& C=\frac{1}{2\left[1-\left(\frac{\theta_{i}}{\theta_{s}}\right)^{\eta}\right](1-\beta)} \ln \left(\frac{1}{\beta}\right)
\end{aligned}
$$

where $\gamma$ (parameter for geometrical correction of the infiltration front shape) and $\beta$ are coefficients that are commonly set at 0.75 and 0.6 for $\theta_{i}<0.25$ $\theta_{s}, r_{d}(\mathrm{~mm})$ is the radius of the disk source, and $\eta$ is a shape parameter that is estimated from the analysis of the particle size data with the pedotransfer function included in the BEST procedure. Note that relations (3) apply only when residual water content is negligible and that these equations are sensitive to the estimation of saturated water content, which may be quite challenging under specific circumstances.

In order to check the impact of the assumed coincidence between saturated soil water content and porosity on the $K_{s}$ calculations, two alternative approaches were applied to estimate the saturated volumetric water content, $\theta_{s}\left(\mathrm{~cm}^{3} \mathrm{~cm}^{-}\right.$ $\left.{ }^{3}\right)$. Following the procedure by Lassabatere et al. (2006), the saturated soil was sampled at the end of each infiltration experiment to determine the saturated gravimetric water content, $w_{s}\left(\mathrm{~g} \mathrm{~g} \mathrm{~g}^{-1}\right)$, and thus $\theta_{s}$ from $\rho_{b}$ and $w_{s}$, considering that water density is $1 \mathrm{~g} \mathrm{~cm}^{-3}\left(\theta_{s, w}=w_{s} \rho_{b}\right)$. With another approach, $\theta_{s}$ was assumed to coincide with soil porosity, $\varepsilon\left(\theta_{s, \varepsilon}=\varepsilon\right)$, as suggested by many authors (Xu et al., 2009; Mubarak et al., 2010; Yilmaz et al., 2010; Bagarello et al., 2011; Di Prima, 2015). Only $\theta_{s, w}$ was considered with reference to the second measurement campaign.

Due to ploughing of the vineyard soils for millennia, the spatial variability of the soil properties is low. Therefore, for all calculations, the site was considered homogeneous in terms of PSD and $\rho_{b}, \varepsilon, \theta_{i}$ and $\theta_{s}$ values. The representative values were obtained by averaging the individual determinations of each variable.
The BEST method was chosen for this investigation since it is one of the simplest experimental methods of soil hydraulic characterization and also because recent investigations have suggested that the method appears promising as a practical alternative to more cumbersome and time consuming methods (Aiello et al., 2014; Alagna et al., 2016a; Bagarello and Iovino, 2012, Bagarello et al., 2014b; Yilmaz et al., 2010). BEST-steady was applied because it allows a particularly simple calculation of $S$ and $K_{s}$ and also because it was expected to yield a higher percentage of success on the infiltration runs, implying more experimental information, as compared to other possible algorithms. Indeed, Di Prima et al. (2016) showed that all BEST derived methods, i.e. BEST-steady, BEST-intercept and BEST-slope led to similar results in most cases, but BESTslope (Lassabatere et al., 2006) and BESTintercept (Yilmaz et al., 2010) algorithms can fail when the transient phase of the infiltration process is not described appropriately. In contrast, BESTsteady is more sensitive to the attainment of steady-state but not sensitive to the description of the transient phase. In this study, we considered that steady-states were attained for all experiments and that BEST-steady was more appropriate and practical.

\subsection{Mini disk infiltrometer runs}

A mini disk infiltrometer (MDI) was applied at exactly the same 14 points sampled on May 2016, 48 hours after the ponding infiltration run, in order to assess the change in hydraulic properties of the soil due to the realization of the Beerkan tests. The pressure head on the porous disk of the device, with a diameter of $45 \mathrm{~mm}$, was set at -5 $\mathrm{mm}$ and no more than $2 \mathrm{~mm}$ of contact material were used. At each sampling point, the infiltration process continued until the reservoir of the device, which has a capacity of $135 \mathrm{~mL}$, emptied. The final soil water content was determined by using a knife to collect a small amount of the wetted soil under the disk a few seconds after the end of the 
infiltration process. To determine the initial soil water content, two additional ponding infiltration runs were carried out and the soil inside the ring was sampled 48 hours later. The recommended method by Decagon Device Inc. (2014) was used to calculate the soil hydraulic conductivity corresponding to a pressure head of $-5 \mathrm{~mm}, K_{-5}$.

The MDI was used in this investigation for different reasons. The source is small, which implies the possibility of performing the MDI run exactly on the area previously subjected to the ponding infiltration process. The run is expected not to alter, or alter only minimally, the infiltration surface (Alagna et al., 2016b). This means that the technique should be appropriate to reveal intrinsic differences in hydrodynamic parameters of different sampling points. The effect of almost all pores on flow of water is taken into account since a high pressure head (close to zero) is established on the porous disk. In other terms, the measured conductivity with the MDI can be considered very close to $K_{s}$ (Alagna et al., 2016b). Finally, the MDI appears usable for estimating infiltration rates of soil crusts ( $\mathrm{Li}$ et al., 2005); which can be of interest when the soil surface crusts.

\subsection{Analytical validation}

A quantitative comparison between the $K_{s}$ and $S$ estimates obtained with the Beerkan runs and the rainfall simulation experiments was also carried out. With this aim, data from the rainfall simulation experiments on the small plots (diameter of $0.09 \mathrm{~m}$ ) were considered since ponding infiltrometer runs were carried out with a $0.085 \mathrm{~m}$ inner-diameter ring. Estimates for $K_{s}$ and $S$ were derived from the rainfall simulation experiments according to (White et al., 1989). For a constant rainfall rate, $R\left(\mathrm{~L} \mathrm{~T}^{-1}\right)$, the time to ponding $t_{p}$ can be expressed as:

$$
t_{p}=\frac{M}{R}\left(\frac{S^{2}}{K_{s}}\right) \ln \left(\frac{R}{R-K_{s}}\right)
$$

where $M$ is a soil-specific parameter determined by the shape of the soil-water diffusivity function, which varies from 0.5 to 0.66 and that can be set equal to 0.55 for practical purposes (White et al., 1989). The analytic expression of $t_{p}$ given by Eq.(4) can be used in the inverse sense to obtain estimates of both $S$ and $K_{s}$ as follows:

$$
\begin{aligned}
& S=\sqrt{1.818 \frac{R(R-r) t_{p}}{\ln \left(\frac{R}{r}\right)}} \\
& K_{s}=R-r
\end{aligned}
$$

where $r\left(\mathrm{~L} \mathrm{~T}^{-1}\right)$ is the steady-state runoff rate.

Table 2. Time to ponding, $t_{p}$ (s), time to runoff, $t_{r}$ (s), runoff coefficient, $R_{c}$ (in \%), and experimental steady-state infiltration rate, $i_{s R}\left(\mathrm{~mm} \mathrm{~h}^{-1}\right)$, for the 0.56 and $0.09 \mathrm{~m}$ diameter plots.

\begin{tabular}{llllll}
\hline Plot diameter & Statistic & $t_{p}$ & $t_{r}$ & $R_{c}$ & $i_{s R}$ \\
\hline 0.56 & $\mathrm{n}$ & 6 & 6 & 6 & 6 \\
& Min & 150 & 180 & 11.9 & 9.3 \\
& Max & 540 & 1260 & 57.8 & 31.1 \\
& Mean & $332 \mathrm{a}$ & $610 \mathrm{c}$ & $31.9 \mathrm{~d}$ & $20.0 \mathrm{e}$ \\
& $\mathrm{CV}$ & 47.0 & 60.8 & 61.1 & 43.2 \\
\hline 0.09 & $\mathrm{n}$ & 7 & 8 & 8 & 8 \\
& Min & 260 & 390 & 7.7 & 2.1 \\
& Max & 1140 & 2650 & 75.7 & 60.3 \\
& Mean & $761 \mathrm{~b}$ & $1308 \mathrm{c}$ & $38.0 \mathrm{~d}$ & $24.4 \mathrm{e}$ \\
& $\mathrm{CV}$ & 45.1 & 70.7 & 73.0 & 76.0 \\
\hline
\end{tabular}

Sample size (n), minimum (Min), maximum (Max), mean, and coefficient of variation (CV, in $\%)$. For a given variable, the values in a column followed by the same lower case letter were not significantly different according to a two tailed $\mathrm{t}$ test $(P=0.05)$.

\section{Results and discussion}

\subsection{Rainfall simulation experiments and runoff measurements}

Table 2 summarizes the time to ponding, time to runoff, runoff coefficient and experimental steady-state infiltration rate values for the 0.56 and $0.09 \mathrm{~m}$ diameter plots. At two plots, one of each size, no surface runoff was generated during the 1-hour simulations. For the other six $0.56 \mathrm{~m}$ diameter plots, the times to ponding and to runoff

Di Prima S, Bagarello V, Lassabatere L, Angulo-Jaramillo R, Bautista I, Burguet M, Cerdà A, Iovino M, Prosdocimi M. 2017. Comparing Beerkan infiltration tests with rainfall simulation experiments for hydraulic characterization of a sandy-loam soil. Hydrological Processes. DOI: 10.1002/hyp.11273 


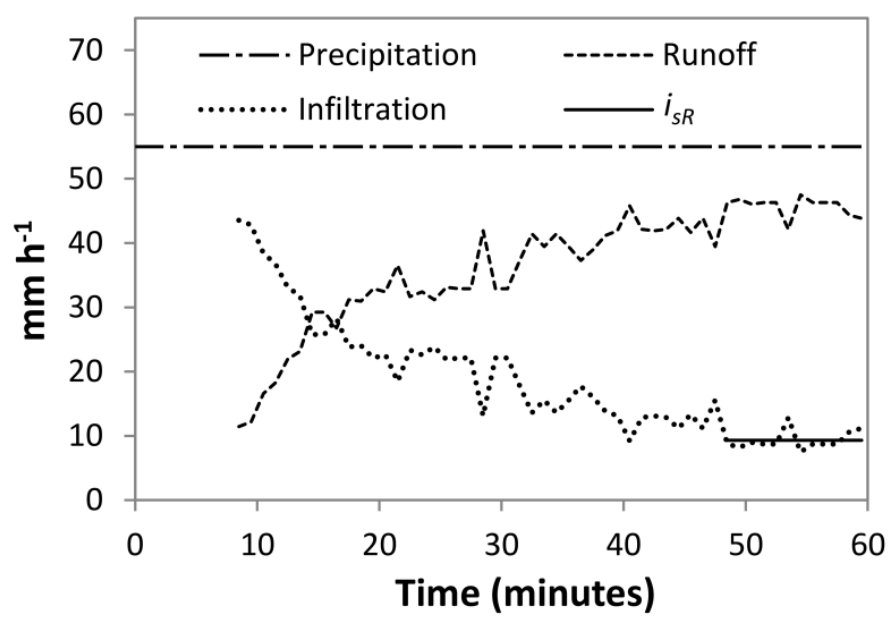

Figure 2. Illustrative example of a 1-hour simulated rainfall on a $0.56 \mathrm{~m}$ diameter plot at 55 $\mathrm{mm} \mathrm{h}^{-1}$ rainfall intensity. The infiltration curve was drawn by subtracting the runoff rate from the intensity. The experimental steady-state infiltration rate, $i_{s R}\left(9.3 \mathrm{~mm} \mathrm{~h}^{-1}\right)$, was estimated considering the last thirteen data points

varied between 150-540 and 180-1260 s, respectively. The runoff coefficient ranged from 11.9 to $57.8 \%$. For the small plots, the time to ponding and to runoff varied between 260-1140 and 390-2650 s. The runoff coefficient ranged from 7.7 to $75.7 \%$.

Experimental steady-state infiltration rates, $i_{s R}$, were reached before the end of all runs, so they were estimated considering the last data points of the infiltration curves. An example is given in Fig. 2 . The $i_{s R}$ values of the 0.56 and $0.09 \mathrm{~m}$ diameter plots ranged from 9.3 to 31.1 (mean value, $\mathrm{M}\left(i_{s R}\right)$ $=20.0 \mathrm{~mm} \mathrm{~h}^{-1}$ ) and from 2.1 to $60.3 \mathrm{~mm} \mathrm{~h}^{-1}$ $\left(\mathrm{M}\left(i_{s R}\right)=24.4 \mathrm{~mm} \mathrm{~h}^{-1}\right)$, respectively. The mean values differed only by a factor of 1.2, suggesting that using different plot sizes did not appreciably affect the estimated infiltration rates, in terms of average values. A slightly larger variability of $t_{r}$, $R_{\mathrm{c}}$ and $i_{\mathrm{S} R}$ was detected with the small plots, showing that an increase in the sampled area implied reduced uncertainties in the estimated mean values of the three variables. However, the plot diameter did not have a statistically detectable effect on the measured $t_{r}, R_{\mathrm{c}}$ and $i_{s R}$ values according to a two-tailed t test at $P=0.05$ (Table
2). The statistical irrelevance of the area on the estimated steady-state infiltration rate by the rainfall simulation experiments implied the possibility of establishing a comparison between the rainfall simulation experiment with a known kinetic energy value and the ponding infiltrometer runs, even if these last runs did not sample the same area. In other words, the comparison in terms of total applied energy between the two methodologies was possible, since the $E_{k}$ value for the specific rainfall simulator and applied intensity was known (Iserloh et al., 2013a).

\subsection{Effect of height on ponded infiltration}

The height from which water was poured influenced the infiltration process since the mean duration of the $\mathrm{H}$ runs, equal to $2236 \mathrm{~s}$ (individual runs lasting from 1134 to 4877 s), was 2.8 times longer than the mean duration of the $L$ runs, equal to $842 \mathrm{~s}$ (individual runs lasting from 590 to 1234

$\mathrm{s}$, Fig. 3a). The ratio $\Delta t_{H} / \Delta t_{L}\left(1.3<\Delta t_{H} / \Delta t_{L}<4.8\right)$ increased with the number of the applied volumes of water (Fig. 3b), indicating that $\Delta t_{H}$ increased more than $\Delta t_{L}$ during the run. Therefore, the differences between $\Delta t_{H}$ and $\Delta t_{L}$ were expressive of a progressive deterioration of the infiltration surface with the repeated application of a given amount of water from a higher height. Disturbance occurred soon, since $\Delta t_{H} / \Delta t_{L}$ was systematically greater than one even in the early stages of the infiltration run, and it increased with a prolonged exposure of the soil surface to water.

Fig. 3c shows two illustrative examples of the $K_{s}$ calculation by BEST-steady. According to the Lilliefors (1967) test, the hypothesis of a normal distribution for the $K_{s L}$ and $K_{s H}$ data, obtained with the $\mathrm{L}$ and $\mathrm{H}$ experiments respectively, was never rejected $(P=0.05)$. Therefore, the data were summarized by calculating the arithmetic mean and the associated coefficient of variation (Table 3). As expected, the estimates of $K_{s}$ increased considering $\theta_{s, \varepsilon}$ instead of $\theta_{s, w}$ (difference by a factor of 1.2) since $A$ is inversely related to $\theta_{s}$ according to Eq.(3a) and larger $K_{s}$ values are obtained with smaller $A$ values according to

Di Prima S, Bagarello V, Lassabatere L, Angulo-Jaramillo R, Bautista I, Burguet M, Cerdà A, Iovino M, Prosdocimi M. 2017. Comparing Beerkan infiltration tests with rainfall simulation experiments for hydraulic characterization of a sandy-loam soil. Hydrological Processes. DOI: 10.1002/hyp.11273 

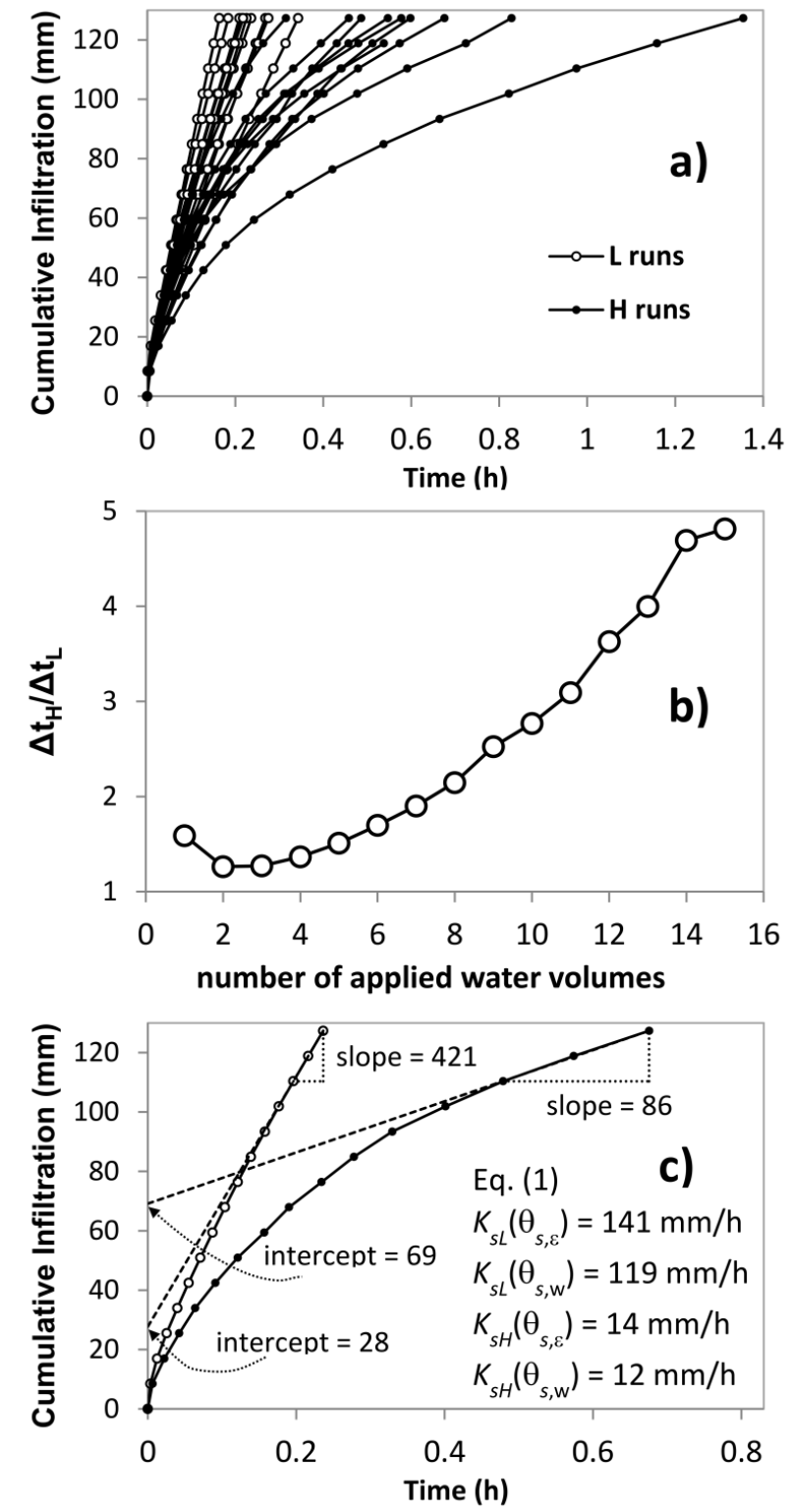

Figure 3. (a) Cumulative infiltration curves for both heights of water pouring. (b) Ratio between the mean infiltration time for a water application height of $0.34 \mathrm{~m}\left(\Delta t_{H}\right)$ and $0.03 \mathrm{~m}\left(\Delta t_{L}\right)$ during the infiltration runs plotted against the number of the applied volumes of water. (c) Illustrative example of the calculation procedure of saturated soil hydraulic conductivity, $K_{s}$, by applying BESTsteady to analyze the measured cumulative infiltration, $I(\mathrm{~mm})$, vs. time, $t(\mathrm{~h})$, data. The slope $i_{S P}\left(\mathrm{~mm} \mathrm{~h}^{-1}\right)$ is the experimental steady-state infiltration rate and $b_{s}(\mathrm{~mm})$ is the experimental intercept of the straight line interpolating the last three $I$ vs. $t$ data points.
Table 3. Sample size (n), minimum (Min), maximum (Max), mean, and coefficient of variation (CV, in \%) of the saturated soil hydraulic conductivity, $K_{s}\left(\mathrm{~mm} \mathrm{~h}^{-1}\right)$, values obtained by pouring water into the cylinder from two different heights, $h_{w}(\mathrm{~m})$, and considering different saturated soil water content values, $\theta_{s}$ $\left(\mathrm{cm}^{3} \mathrm{~cm}^{-3}\right)$.

\begin{tabular}{|c|c|c|c|c|}
\hline \multirow{3}{*}{$\begin{array}{l}\theta_{s} \\
h_{w}\end{array}$} & \multicolumn{4}{|c|}{$K_{s}$} \\
\hline & \multicolumn{2}{|c|}{0.44} & \multicolumn{2}{|c|}{0.52} \\
\hline & 0.03 & 0.34 & 0.03 & 0.34 \\
\hline $\mathrm{n}$ & 10 & 10 & 10 & 10 \\
\hline Min & 95.2 & 6.3 & 112.0 & 7.7 \\
\hline Max & 259.7 & 26.0 & 300.0 & 31.8 \\
\hline Mean & $146.2 \mathrm{a}$ & $15.2 \mathrm{~b}$ & $171.6 \mathrm{a}$ & $18.7 \mathrm{~b}$ \\
\hline CV & 35.1 & 42.7 & 33.9 & 42.4 \\
\hline
\end{tabular}

For a given saturated soil water content value, values followed by a different lower case letter were significantly different according to a two tailed test $(P=0.05)$.

Eq.(2). Nevertheless, the assumed coincidence between saturated soil water content and porosity, as an alternative approach to the direct measurement of $\theta_{s}$, did not have a strong effect on the estimated $K_{s}$ values since rather similar estimates were obtained with both $\theta_{s}$ values.

In both cases, the average $K_{s}$ values obtained with the $\mathrm{L}$ experiments, $\mathrm{M}\left(K_{s L}\right)$, were higher than the expected saturated conductivity on the basis of the soil textural characteristics alone, e.g. $K_{s}=$ $44.2 \mathrm{~mm} \mathrm{~h}^{-1}$ for a sandy-loam soil according to Carsel and Parrish (1988). This suggested that soil macroporosity in the ploughed horizon might have influenced the results (Josa et al., 2010; Alagna et al., 2016a). The effect of the height from which water was poured on $K_{s}$ was statistically significant and also noticeable, as $\mathrm{M}\left(K_{s L}\right)$ was around 10 times higher than $\mathrm{M}\left(K_{s H}\right)$ (means of $K_{s}$ obtained with high runs). This result was in line with the suggestion by Bagarello et al. (2014a) and Alagna et al. (2016a) that a larger height from which water was poured, i.e. more energy delivered to the soil surface, implied more opportunities for aggregate breakdown, compaction of the exposed soil surface and macropore obstruction. 
For another sandy-loam soil located in Sicily (Italy), with an initial soil water content (0.12 $0.16 \mathrm{~cm}^{3} \mathrm{~cm}^{-3}$ ) similar to the mean $\theta_{i}$ of the sampled soil in this investigation $\left(0.14 \mathrm{~cm}^{3} \mathrm{~cm}^{-3}\right)$, $M\left(K_{s L}\right)$ was equal to 299.2 - $496.4 \mathrm{~mm} \mathrm{~h}^{-1}$ (Alagna et al., 2016a), i.e. it differed from the $M\left(K_{s L}\right)$ value of this investigation by a factor of 1.7-3.4. On the other hand, the $\mathrm{M}\left(K_{s H}\right)$ value obtained in the Spanish soil was very close to those by Alagna et al. (2016a), i.e. $12.8-18.9 \mathrm{~mm}$ $\mathrm{h}^{-1}$, supporting their conclusion that the $\mathrm{H}$ runs could allow the estimation of similar $K_{s}$ for soils with a similar texture.

The BEST method is dedicated to non-layered soils that should also be uniform and with a uniform soil water content at the beginning of the infiltration run (Lassabatere et al., 2006, 2009) and contain no macropore network (Lassabatere et al., 2014). However, completely homogeneous soils probably do not exist in natural environments (Reynolds and Elrick, 2002). Therefore, the hydraulic conductivity obtained by an infiltrometer method, such as BEST, should probably be considered as an equivalent conductivity, i.e. the conductivity of a rigid, homogeneous and isotropic porous medium characterized by infiltration rates that are those actually measured on real soils (Bagarello et al., 2010). For the case of stratified media, the layer with the lowest hydraulic conductivity may rule flow and consequently cumulative infiltration at the surface. Therefore, water infiltration data can be regarded as more representative of the hydraulic behavior of the less permeable layer, and BEST parameters may be assigned to the less permeable layer. Such an approach was proposed by Lassabatere et al. (2010) for a stratified medium with a low permeability sedimentary layer at the surface. The ability of the BEST method to distinguish between crusted and noncrusted soils was also demonstrated by Souza et al. (2014). The experiments presented in this study support these previous findings and suggest that if any crust forms at the surface, Beerkan infiltration tests should detect the impact on flow and BEST estimates should better characterize the hydraulic properties of the crust.

\subsection{Comparing infiltrometer runs against rainfall simulation experiments}

Capillary flow effects in the late phase of the simulated rainfall were likely negligible since the buffer area avoided edge effects around the ring. This circumstance likely determined a nearvertical wetting front, i.e. a one-dimensional process, in the soil volume underlying the confined plot surface. On the other hand, 3-D infiltration experiments were carried out according to the BEST procedure. Therefore, the comparison between the infiltrometer run and the rainfall simulation experiment cannot be established in terms of steady-state infiltration rates due to the differences in flow dimension and therefore requires additional consideration.

At steady state, vertical infiltration rates under a null pressure head on the infiltration surface approach $K_{s}$ (Reynolds et al., 2000). Therefore, a comparison was established between the $i_{s R}$ data and the saturated soil hydraulic conductivity values, $K_{s L}$ and $K_{s H}$. This comparison allowed us to discriminate between possible $\left(i_{s R} \geq K_{s}\right)$ and physically impossible $\left(i_{s R}<K_{s}\right)$ situations. Indeed, considering a homogeneous soil with constant hydraulic properties submitted to rainfall simulation tests, infiltration rate should always be higher than saturated hydraulic conductivity, and the steady-state infiltration rate should approach the value of the saturated hydraulic conductivity at the end. As a result, if we consider that all the data correspond to the same soil and the same physics, the estimates for saturated hydraulic conductivity derived from ponding infiltration tests should remain lower than the estimate for 1D steady-state infiltration rates derived from the rainfall simulation tests. However, this was not necessarily the case. For the rainfall simulation experiment, the data obtained for both plot types (0.56 and 0.09 m diameter) were considered given the similarity of the collected experimental information in the two cases. As shown in Fig. 4, 


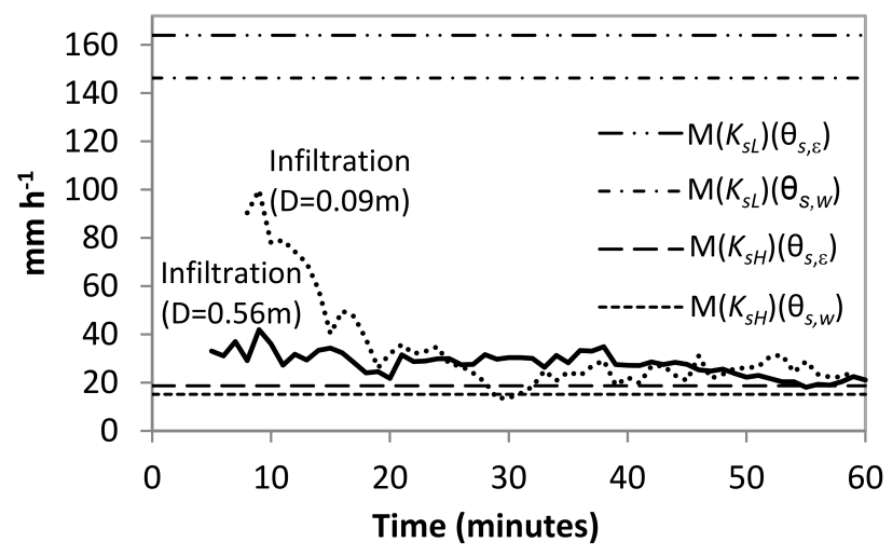

Figure 4. Comparison between the mean $K_{s}$ values obtained by pouring water into the cylinder from two different heights ( $\mathrm{L}$ and $\mathrm{H}$ runs) and considering different saturated soil water content values $\left(\theta_{s, w}\right.$ and $\left.\theta_{s, \varepsilon}\right)$, and mean infiltration rates of the rainfall simulation experiments for the $0.09 \mathrm{~m}$ and $0.56 \mathrm{~m}$ diameter plots

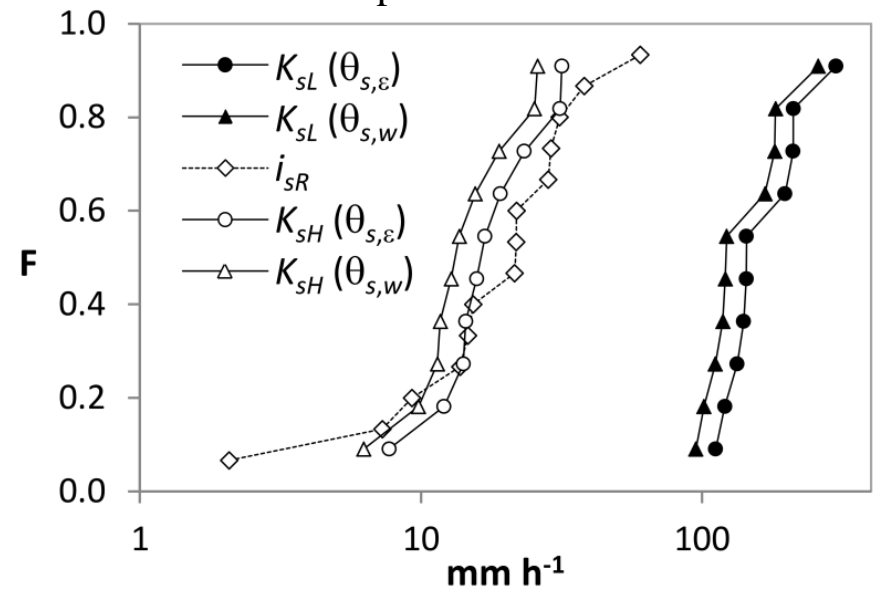

Figure 5. Cumulative empirical frequency distribution of the steady-state infiltration rates of the rainfall simulation experiments, $i_{S R}$ (for both the 0.09 and $0.56 \mathrm{~m}$ diameter plots), and the saturated soil hydraulic conductivity, $K_{s}$ (for both $\theta_{s}$ values), obtained by pouring water into the cylinder from two different heights ( $\mathrm{L}$ and $\mathrm{H}$ runs).

physically possible mean values of $K_{s}$ were obtained with the $\mathrm{H}$ runs $\left(i_{s R}>\mathrm{M}\left(K_{s H}\right)\right)$ regardless of the estimate of $\theta_{s}\left(\theta_{s, w}, \theta_{s, \varepsilon}\right)$. On the other hand, both $\mathrm{M}\left(K_{s L}\right)$ values greatly exceeded $\mathrm{M}\left(i_{s R}\right)$, denoting a physically impossible situation while considering the same homogeneous soil with constant hydraulic properties for the ponded infiltrations with low height for water pouring and rainfall simulation experiments. In other words, physical mechanisms were not comparable between these last two experiments, with additional soil structure disturbance for the rainfall simulation experiments. Conversely, concordant results were found for the ponded infiltration with high height of water pouring and rainfall simulation experiments. These results supported the suggestion by Bagarello et al. (2014a) and Alagna et al. (2016a) that the $K_{s}$ values determined by applying water at a relatively large distance from the soil surface were more appropriate than those obtained with a low height of water pouring to explain surface runoff generation phenomena during intense storms. In particular, $K_{s H}$ values were in line with the occurrence of the measured runoff, while $K_{s L}$ values precluded it (Fig. 5).

Taking into account that both the rainfall simulation experiment and the $\mathrm{H}$ runs determined some kind of soil surface alteration, this comparison suggested that the perturbation factors (droplet impact during rainfall and height from which water was poured) had a similar effect on the measured parameters. So, we can conclude that linking applied methodologies through the kinetic energy of rainfall and the gravitational potential energy of water used for the infiltration runs allowed us to establish a physical link between the simulated hydrological process and the proposed methodology.

The BEST method of soil hydraulic characterization is easy to apply over large areas since the equipment that has to be transported is minimal and small volumes of water are enough to conduct a field infiltration run. Beerkan runs with high heights of pouring give similar information to rainfall simulations but are much easier to conduct as compared with these latter runs. Beerkan tests can simply be replicated to develop a large number of sampling points, which means that intensively sampling large or relatively large areas is a real possibility (Gonzalez-Sosa et al., 2010). The importance of an intensive point 
sampling to reproduce accurately the spatial organization of $K_{s}$ and hence explain soil hydrological processes was demonstrated, for example, by Zimmermann et al. (2013) and Bagarello et al. (2010, 2013). According to Vandervaere et al. (1998), the conductivity measured at the $1-\mathrm{m}^{2}$ scale by tension infiltrometers remains a relevant parameter even for the study of processes at much larger scales. Furthermore, Bodhinayake et al. (2004) showed that unsaturated and ponding infiltration measurements could not vary substantially as the field slope increases up to $20 \%$ (or $11^{\circ}$ ). Therefore, the methodology applied in this investigation could also be used, or at least tested, on areas steeper than $3^{\circ}$.

\subsection{Comparing ponding and mini disk infiltrometer runs}

This campaign, constituted by Beerkan experiments of type $\mathrm{H}$ and $\mathrm{L}$ followed by mini disk infiltrometer tests, was aimed at checking the effect of Beerkan tests on soil surface hydraulic conductivity with an alternative procedure. The initial soil water content was similar for the ponding infiltration runs $\left(\theta_{i}=0.061 \mathrm{~cm}^{3} \mathrm{~cm}^{-3}\right)$ and the MDI runs $\left(\theta_{i}=0.076 \mathrm{~cm}^{3} \mathrm{~cm}^{-3}\right)$.

For this campaign, the $\mathrm{L}$ runs yielded 3.5 times higher $K_{s}$ values than the $\mathrm{H}$ runs and the differences between the two datasets were statistically significant at $P=0.05$ (Table 4). Therefore, the effect of the height of pouring on the $K_{s}$ determinations was similar to that detected earlier in this investigation and also in other investigations (Bagarello et al., 2014a; Alagna et al., 2016a). The MDI yielded $K_{-5}$ values that were 2.3 times higher at the $\mathrm{L}$ sites than in the $\mathrm{H}$ sites, and also the differences between the two $K_{-5}$ datasets (L, H) were statistically significant (Table 4).

Taking into account that the MDI was not expected to alter appreciably the sampled surfaces, the information collected with the MDI runs was that saturated or close to saturation hydraulic conductivity was lower at the $\mathrm{H}$ sites
Table 4. Sample size (n), minimum (Min), maximum (Max), mean, and coefficient of variation $\left(\mathrm{CV}\right.$, in \%) of the saturated, $K_{s}\left(\mathrm{~mm} \mathrm{~h}^{-1}\right)$, and unsaturated, $K_{-5}\left(\mathrm{~mm} \mathrm{~h}^{-1}\right)$, soil hydraulic conductivity values.

\begin{tabular}{llll}
\hline$h_{w}(\mathrm{~m})$ & Variable & $K_{s}$ & $K_{-5}$ \\
\hline 0.03 & $\mathrm{n}$ & 7 & 7 \\
& Min & 91.4 & 85.8 \\
& Max & 156.6 & 119.1 \\
& Mean & $126.3 \mathrm{a}$ & $100.6 \mathrm{a}$ \\
& $\mathrm{CV}$ & 17.5 & 12.5 \\
\hline 0.34 & $\mathrm{n}$ & 7 & 6 \\
& Min & 19.3 & 23.3 \\
& Max & 72.3 & 59.0 \\
& Mean & $35.7 \mathrm{~b}$ & $43.4 \mathrm{~b}$ \\
& CV & 58.7 & 35.8 \\
\hline
\end{tabular}

All $K_{-5}$ data were collected with the a Mini disk Infiltrometer and identical experimental procedures. The $K_{-5}$ data corresponding to a height of water pouring, $h_{w}$, of $0.03 \mathrm{~m}(0.34 \mathrm{~m})$ in the table were obtained at the locations previously sampled with a Beerkan run and a low (high) height of water pouring.

For a given variable, the values in a column followed by a different lower case letter were significantly different according to a two tailed $\mathrm{t}$ test $(P=0.05)$.

than the L ones. Soil sampling was carried out randomly and the sampled surfaces did not exhibit singularities before the ponding infiltration runs, i.e. all surfaces appeared similar. Moreover, experiments carried out at the $\mathrm{H}$ sites seemed to perturb soil surface, in contrast to the $\mathrm{L}$ sites. Therefore, the MDI experiment confirmed independently that soil alteration during the Beerkan tests, reducing soil hydraulic conductivity, was particularly noticeable when a high height of water pouring was used.

Possible mechanisms reducing hydraulic conductivity of saturated or near-saturated soil upon wetting are known to be compaction, mechanical breakdown, slaking, swelling, and physical-chemical dispersion (Le Bissonnais, 1996; Souza et al., 2014). Slaking, swelling and 


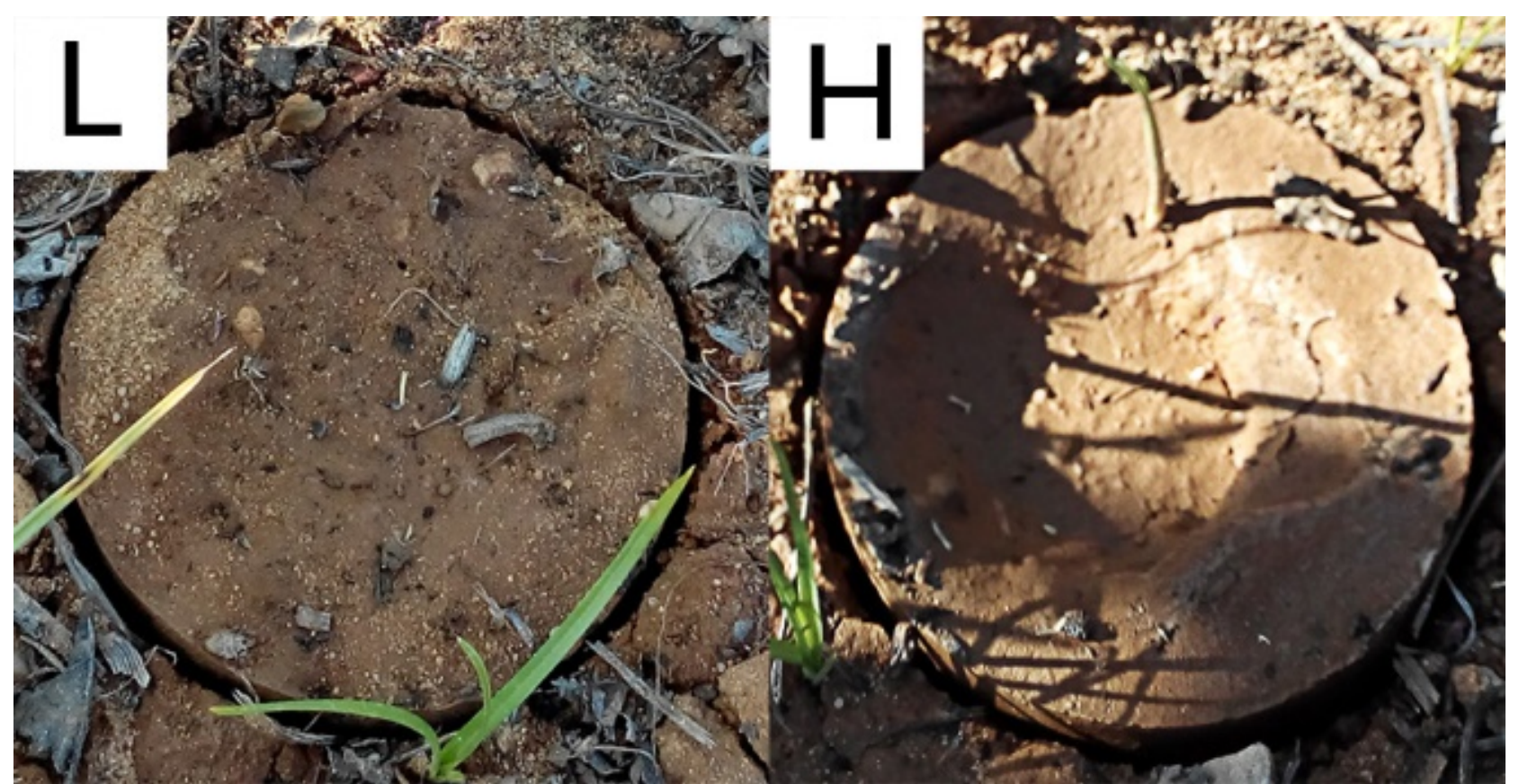

Figure 6. View of the infiltration surfaces after a Beerkan run conducted at low (L) and high (H) height of water pouring.

dispersion were not considered to be relevant mechanisms determining differences between the $\mathrm{L}$ and the $\mathrm{H}$ runs since i) ponding conditions were suddenly established on both types of site, which implies a similarity between possible slaking phenomena, ii) the same volume of water infiltrated the soil and, in any case, the soil was not particularly rich in clay particles, which suggested similar and presumably moderate swelling phenomena at the $\mathrm{L}$ and $\mathrm{H}$ sites, and iii) the same tap water was used for all infiltration runs, suggesting that there is no reason to expect that dispersion was promoted and also that it was similar at the two site types if it occurred to a certain degree. Instead, $\mathrm{L}$ and $\mathrm{H}$ runs differed intentionally by the applied energy to the soil surface. More energy implies more opportunities to compaction and aggregate breakdown to a certain state of disruption (e.g., Angulo-Jaramillo et al., 2016; Cerdà, 1998, 2000). Therefore, compaction and mechanical breakdown, as also suggested by visual examination of the infiltration surfaces after the field runs (Fig.6), appeared to be the most plausible cause of the detected height effects.

\subsection{Using rainfall simulator data to predict soil hydraulic properties}

No statistical differences were detected according to the Tukey Honestly Significant Difference test $(P=0.05)$ between the $S$ and $K_{s}$ values estimated by Eqs. (5) and (6), and those obtained with $\mathrm{H}$ runs by Eqs. (1) and (2), respectively (Table 5). On the other hand, the L runs yielded significantly higher $S$ and $K_{s}$ values as compared with both rainfall simulation and the $\mathrm{H}$ runs. These results showed that the rainfall simulation experiments and the Beerkan $\mathrm{H}$ runs led to similar, and also plausible, $S$ and $K_{s}$ values and both approaches were able to account for soil sealing during rainfall events with high intensities. On the other hand, the Beerkan L runs overestimated the capability of the soil to infiltrate water during rainfall events with high intensities. These results mean also that when the hydraulic properties of soils are targeted without any disturbance of soil structure, Beerkan runs with low height of pouring water should be used. Conversely, when the change in soil structure during rainfall event and its consequences on 
Table 5. Comparison of sorptivity, $S\left(\mathrm{~mm} \mathrm{~h}^{-0.5}\right)$, and saturated soil hydraulic conductivity, $K_{s}(\mathrm{~mm}$ $\mathrm{h}^{-1}$ ), obtained with the rainfall simulation experiments and the BEST procedure with two different heights of water pouring

\begin{tabular}{llll}
\hline Rainfall simulator & Statistic & $S[$ Eq.(5)] & $K_{s}$ Eq. (6)] \\
\cline { 3 - 4 }$(\mathrm{D}=0.09 \mathrm{~m})$ & $\mathrm{n}$ & 7 & 7 \\
& Min & 23.6 & 2.1 \\
& Max & 55.0 & 60.3 \\
& Mean & $35.7 \mathrm{a}$ & $23.7 \mathrm{c}$ \\
& $\mathrm{CV}$ & 37.9 & 83.9 \\
\hline BEST $\left(\theta_{s}=0.44\right)$ & & $S_{H}$ & $K_{s H}$ \\
\cline { 3 - 4 } & $\mathrm{n}$ & 10 & 10 \\
& Min & 25.6 & 6.3 \\
& Max & 52.3 & 26.0 \\
& Mean & $38.9 \mathrm{a}$ & $15.2 \mathrm{c}$ \\
& $\mathrm{CV}$ & 19.3 & 42.7 \\
\cline { 2 - 3 } & & $S_{L}$ & $K_{S L}$ \\
\cline { 2 - 3 } & $\mathrm{n}$ & 10 & 10 \\
& Min & 59.4 & 95.2 \\
Max & 83.7 & 259.7 \\
Mean & $72.6 \mathrm{~b}$ & $146.2 \mathrm{~d}$ \\
CV & 9.8 & 35.1 \\
\hline
\end{tabular}

Sample size (n), minimum (Min), maximum (Max), mean, and coefficient of variation (CV, in $\%)$.

For a given variable, the values followed by the same lower case letter were not significantly different according to the Tukey Honestly Significant Difference test $(P=0.05)$. The values followed by a different lower case letter were significantly different.

water runoff are targeted, either rainfall simulator or Beerkan tests with a high height of pouring water should be used. Since these last runs give similar results to the rainfall simulator, while being much less costly and time consuming, they appear as a promising tool for the characterization of soil hydraulic behavior under intense rainfall events.

\section{Conclusions}

A sandy-loam soil was sampled at El Celler del Roure in Les Alcusses de Moixent (Valencia, southeast Spain), with rainfall simulation experiments, the BEST procedure carried out with two heights of water application (0.03 and $0.34 \mathrm{~m})$ and mini disk infiltrometer (MDI) experiments. The height from which water was poured onto the infiltration surface influenced significantly the measurement of the saturated soil hydraulic conductivity, $K_{s}$, with the low (L) runs yielding higher mean values than the high $(\mathrm{H})$ runs by approximately one order of magnitude. The latter values were in line with the results from rainfall simulation experiments. Indeed, plausible $K_{s}$ values were only obtained with the $H$ runs since they were lower and of the same order of magnitude as the infiltration rates measured with rainfall simulation. Therefore, $K_{s}$ values determined by applying water at a relatively large distance from the soil surface were more appropriate to predict surface runoff generation phenomena during intense storms. In particular, the $\mathrm{H}$ procedure yielded $K_{s}$ values in line with the occurrence of the measured runoff, while the $\mathrm{L}$ procedure estimations precluded it. We attributed this discrepancy to the change in the physics of water infiltration and changes in soil structure. In the case of $\mathrm{H}$ runs and rainfall simulation experiments, the kinetic and gravitational potential energy of water drops may have impacted soil structure at surface, thus reducing water infiltration. Visually, the change in soil structure at surface was evident. In addition, complementary experiments (MDI experiment) demonstrated that this change was responsible for a large decrease in hydraulic conductivity. This phenomenon was mainly expressive of compaction and mechanical breakdown processes since slaking, swelling and dispersion depend on factors that did not change between the $\mathrm{L}$ and $\mathrm{H}$ sites. Thus, Beerkan tests with high height of water pouring should be performed when the understanding of soil hydraulic behavior is targeted for intense storm events.

The imposed coincidence of the soil alteration severity between the simulated rainfall and infiltrometer runs, expressed as kinetic and gravitational potential energy of the applied water respectively, determined a similar impact on the measured hydraulic parameters. In the future, 
estimating $E_{k}$ at different applied intensities, using disdrometers and optical rain spectrometers, and setting up the infiltrometer tests with a height of water pouring whereby $E_{p} \approx E_{k}$ could allow for the assessment of the established physical link between the hydrological processes measured with rainfall simulation experiments and the proposed methodology for characterizing the soil.

In conclusion, the hypothesis that the height from which water is poured onto the soil surface is a parameter useful in infiltration experiments to mimic the effect of high intensity rain on the soil hydraulic properties was demonstrated. It was also demonstrated that this kind of test could accurately mimic rainfall simulation experiments. This study investigated the case of a sandy loam soil. However, this procedure should be tested for soils with different texture and structural stability and different initial moisture conditions in an attempt to improve our ability to use measured soil properties for both interpreting and simulating hydrological processes, including runoff generation phenomena. Establishing a link between the process to be simulated and the applied soil hydraulic characterization method is a topic meriting specific research, although solving the problem is not easy. A factor that has to be considered is that infiltration tests are commonly performed with constant boundary conditions at the soil surface. However, intensities are prone to time variation during a rainfall event, which implies that mechanisms of soil response to wetting may change during the event and between events. Recovery of soil hydraulic properties between two events should also be taken into account.

\section{Acknowledgements}

The research leading to these results has received funding from the European Union Seventh Framework Programme (FP7/2007-2013) under grant agreement $\mathrm{n}^{\circ} 603498$ (RECARE project), and from the Università degli Studi di Palermo (Dottorato di Ricerca in Sistemi AgroAmbientali, indirizzo Idronomia Ambientale). The authors also thank N. Pradetto Sordo for her assistance in the field activity. S.D.P. also thanks I.A., B.F. and A.H.

\section{References}

Aiello R, Bagarello V, Barbagallo S, Consoli S, Di Prima S, Giordano G, Iovino M. 2014. An assessment of the Beerkan method for determining the hydraulic properties of a sandy loam soil. Geoderma 235-236: 300-307 DOI: 10.1016/j.geoderma.2014.07.024

Alagna V, Bagarello V, Di Prima S, Giordano G, Iovino M. 2016a. Testing infiltration run effects on the estimated water transmission properties of a sandy-loam soil. Geoderma 267: 24-33 DOI: 10.1016/j.geoderma.2015.12.029

Alagna V, Bagarello V, Di Prima S, Iovino M. 2016b. Determining hydraulic properties of a loam soil by alternative infiltrometer techniques. Hydrological Processes 30 (2): 263-275 DOI: 10.1002/hyp.10607

Angulo-Jaramillo R, Bagarello V, Iovino M, Lassabatere L. 2016. Infiltration measurements for soil hydraulic characterization. Springer International Publishing.

Bagarello V, Castellini M, Di Prima S, Iovino M. 2014a. Soil hydraulic properties determined by infiltration experiments and different heights of water pouring. Geoderma 213: 492-501 DOI: 10.1016/j.geoderma.2013.08.032

Bagarello V, Di Prima S, Iovino M. 2014b. Comparing alternative algorithms to analyze the beerkan infiltration experiment. Soil Science Society of America Journal 78 (3): 724 DOI: 10.2136/sssaj2013.06.0231

Bagarello V, Di Prima S, Iovino M, Provenzano G, Sgroi A. 2011. Testing different approaches to characterize Burundian soils by the BEST procedure. Geoderma 162 (1-2): 141-150 DOI: 10.1016/j.geoderma.2011.01.014

Bagarello V, Di Stefano C, Iovino M, Sgroi A. 2013. Using a transient infiltrometric technique for intensively sampling field-saturated hydraulic conductivity of a clay soil in two runoff plots. Hydrological Processes 27 (24): 3415-3423 DOI: 10.1002/hyp.9448

Bagarello V, Di Stefano C, Ferro V, Iovino M, Sgroi A. 2010. Physical and hydraulic characterization of a clay soil at the plot scale. Journal of Hydrology 387 (1-2): 5464 DOI: 10.1016/j.jhydrol.2010.03.029

Bagarello V, Iovino M. 2012. Testing the BEST procedure to estimate the soil water retention curve. Geoderma 187188: 67-76 DOI: 10.1016/j.geoderma.2012.04.006

Bagarello V, Iovino M, Elrick D. 2004. A simplified falling-head technique for rapid determination of fieldsaturated hydraulic conductivity. Soil Science Society of America Journal 68 (1): 66 DOI: 10.2136/sssaj2004.6600 Bhardwaj A, Singh R. 1992. Development of a portable rainfall simulator infiltrometer for infiltration, runoff and 
erosion studies. Agricultural Water Management 22 (3): 235-248 DOI: 10.1016/0378-3774(92)90028-U

Bouma J. 1982. Measuring the hydraulic conductivity of soil horizons with continuous macropores1. Soil Science Society of America Journal 46 (2): 438 DOI: 10.2136/sssaj1982.03615995004600020047x

Bowyer-Bower TAS, Burt TP. 1989. Rainfall simulators for investigating soil response to rainfall. Soil Technology 2 (1): 1-16 DOI: 10.1016/S0933-3630(89)80002-9

Brakensiek DL, Rawls WJ. 1983. Agricultural management effects on soil water processes, part II: Green and Ampt parameters for crusting soils. Transactions - American Society of Agricultural Engineers 26 (6): 1753-1757

Bodhinayake W, Si BC, Noborio K. 2004. Determination of hydraulic properties in sloping landscapes from tension and double-ring infiltrometers. Vadose Zone Journal 3 (3): 964 DOI: 10.2136/vzj2004.0964

Brooks RH, Corey T. 1964. Hydraulic properties of porous media. Hydrol. Paper 3., Colorado State University, Fort Collins.

Carsel RF, Parrish RS. 1988. Developing joint probability distributions of soil water retention characteristics. Water Resources Research 24 (5): 755-769 DOI: 10.1029/WR024i005p00755

Cassinari C, Manfredi P, Giupponi L, Trevisan M, Piccini C. 2015. Relationship between hydraulic properties and plant coverage of the closed-landfill soils in Piacenza (Po Valley, Italy). Solid Earth 6 (3): 929-943 DOI: 10.5194/se-6-929-2015

Castillo FE, Beltrán LR. 1979. Precipitaciones máximas en España: estimaciones basadas en métodos estadísticos. Servicio de Publicaciones Agrarias, Ministerio de Agricultura.

Cerdà A. 1996. Seasonal variability of infiltration rates under contrasting slope conditions in southeast Spain. Geoderma 69 (3-4): 217-232 DOI: 10.1016/00167061(95)00062-3

Cerdà A. 1997. Seasonal changes of the infiltration rates in a Mediterranean scrubland on limestone. Journal of Hydrology 198 (1-4): 209-225 DOI: 10.1016/S00221694(96)03295-7

Cerdà A. 1998. Changes in overland flow and infiltration after a rangeland fire in a Mediterranean scrubland. Hydrological Processes 12 (7): 1031-1042 DOI: 10.1002/(SICI)1099-1085(19980615)12:7<1031::AIDHYP636>3.0.CO;2-V

Cerdà A. 1999. Seasonal and spatial variations in infiltration rates in badland surfaces under Mediterranean climatic conditions. Water Resources Research 35 (1): 319-328 DOI: 10.1029/98WR01659

Cerdà A. 2000. Aggregate stability against water forces under different climates on agriculture land and scrubland in southern Bolivia. Soil and Tillage Research 57 (3): 159-166 DOI: 10.1016/S0167-1987(00)00155-0
Cerdà A. 2001. Effects of rock fragment cover on soil infiltration, interrill runoff and erosion. European Journal of Soil Science 52 (1): 59-68 DOI: 10.1046/j.13652389.2001.00354.x

Cerdà A, Ibáñez S, Calvo A. 1997. Design and operation of a small and portable rainfall simulator for rugged terrain. Soil Technology 11 (2): 163-170 DOI: 10.1016/S0933-3630(96)00135-3Diodato N, Verstraeten G, Bellocchi G. 2014. Decadal modelling of rainfall erosivity in Belgium. Land Degradation \& Development 25 (6): 511-519 DOI: 10.1002/ldr.2168

Di Prima S. 2015. Automated single ring infiltrometer with a low-cost microcontroller circuit. Computers and Electronics in Agriculture 118: 390-395 DOI: 10.1016/j.compag.2015.09.022

Di Prima S, Lassabatere L, Bagarello V, Iovino $\mathrm{M}$, Angulo-Jaramillo R. 2016. Testing a new automated single ring infiltrometer for Beerkan infiltration experiments. Geoderma 262: 20-34 DOI: 10.1016/j.geoderma.2015.08.006

Gee GW, Bauder JW. 1986. Particle-size Analysis. In SSSA Book SeriesSoil Science Society of America, American Society of Agronomy; 383-411.

Gonzalez-Sosa E, Braud I, Dehotin J, Lassabatere L, Angulo-Jaramillo R, Lagouy M, Branger F, Jacqueminet C, Kermadi S, Michel K. 2010. Impact of land use on the hydraulic properties of the topsoil in a small French catchment. Hydrological Processes 24 (17): 2382-2399 DOI: 10.1002/hyp.7640

Haverkamp R, Ross PJ, Smettem KRJ, Parlange JY. 1994. Three-dimensional analysis of infiltration from the disc infiltrometer: 2. Physically based infiltration equation. Water Resources Research 30 (11): 2931-2935 DOI: 10.1029/94WR01788

Iovino M, Castellini M, Bagarello V, Giordano G. 2016. Using static and dynamic indicators to evaluate soil physical quality in a Sicilian area. Land Degradation \& Development 27 (2): 200-210 DOI: 10.1002/ldr.2263

Iserloh T, Ries JB, Arnáez J, Boix-Fayos C, Butzen V, Cerdà A, Echeverría MT, Fernández-Gálvez J, Fister W, Geißler C, et al. 2013a. European small portable rainfall simulators: A comparison of rainfall characteristics. CATENA 110: 100-112 DOI: 10.1016/j.catena.2013.05.013

Iserloh T, Ries JB, Cerdà A, Echeverría MT, Fister W, Geißler C, N. J. Kuhn, León FJ, Peters P, Schindewolf M, et al. 2013b. Comparative measurements with seven rainfall simulators on uniform bare fallow land. Zeitschrift für Geomorphologie, Supplementary Issues 57 (1): 11-26 DOI: 10.1127/0372-8854/2012/S-00085

Josa R, Ginovart M, Solé A, others. 2010. Effects of two tillage techniques on soil macroporosity in sub-humid environment. Int. Agrophys 24: 139-147

Keesstra S, Pereira P, Novara A, Brevik EC, AzorinMolina C, Parras-Alcántara L, Jordán A, Cerdà A. 2016. Effects of soil management techniques on soil water

Di Prima S, Bagarello V, Lassabatere L, Angulo-Jaramillo R, Bautista I, Burguet M, Cerdà A, Iovino M, Prosdocimi M. 2017. Comparing Beerkan infiltration tests with rainfall simulation experiments for hydraulic characterization of a sandy-loam soil. Hydrological Processes. DOI: 10.1002/hyp.11273 
erosion in apricot orchards. Science of The Total Environment 551-552: 357-366 DOI: 10.1016/j.scitotenv.2016.01.182

King BA, Bjorneberg DL. 2012. Transient soil surface sealing and infiltration model for bare soil under droplet impact. Transactions of the ASABE 55 (3): 937-945

Lado M, Paz A, Ben-Hur M. 2004. Organic matter and aggregate-size interactions in saturated hydraulic conductivity. Soil Science Society of America Journal 68 (1): 234 DOI: 10.2136/sssaj2004.2340

Lassabatere L, Yilmaz D, Peyrard X, Peyneau PE, Lenoir T, Šimůnek J, Angulo-Jaramillo R. 2014. New analytical model for cumulative infiltration into dualpermeability soils. Vadose Zone Journal 13 (12), doi:10.2136/vzj2013.10.0181

Lassabatere L, Angulo-Jaramillo R, Goutaland D, Letellier L, Gaudet JP, Winiarski T, Delolme C. 2010. Effect of the settlement of sediments on water infiltration in two urban infiltration basins. Geoderma 156 (3-4): 316-325 DOI: 10.1016/j.geoderma.2010.02.031

Lassabatere L, Angulo-Jaramillo R, Soria-Ugalde JM, Simunek J, Haverkamp R. 2009. Numerical evaluation of a set of analytical infiltration equations. Water Resources Research 45, W12415, DOI:10.1029/2009WR007941

Lassabatere L, Angulo-Jaramillo R, Soria Ugalde JM, Cuenca R, Braud I, Haverkamp R. 2006. Beerkan estimation of soil transfer parameters through infiltration experiments-BEST. Soil Science Society of America Journal 70 (2): 521 DOI: 10.2136/sssaj2005.0026

Lassu T, Seeger M, Peters P, Keesstra SD. 2015. The wageningen rainfall simulator: set-up and calibration of an indoor nozzle-type rainfall simulator for soil erosion studies. Land Degradation \& Development 26 (6): 604612 DOI: 10.1002/ldr.2360

Le Bissonnais Y le. 1996. Aggregate stability and assessment of soil crustability and erodibility: I. Theory and methodology. European Journal of Soil Science 47 (4): 425-437 Available at: http://onlinelibrary.wiley.com/doi/10.1111/j.13652389.1996.tb01843.x/full [Accessed 27 January 2015]

Li X-Y, González A, Solé-Benet A. 2005. Laboratory methods for the estimation of infiltration rate of soil crusts in the Tabernas Desert badlands. CATENA 60 (3): 255-266 DOI: 10.1016/j.catena.2004.12.004

Lilliefors HW. 1967. On the Kolmogorov-Smirnov test for normality with mean and variance unknown. Journal of the American Statistical Association 62 (318): 399-402 DOI: 10.1080/01621459.1967.10482916

Liu H, Lei TW, Zhao J, Yuan CP, Fan YT, Qu LQ. 2011. Effects of rainfall intensity and antecedent soil water content on soil infiltrability under rainfall conditions using the run off-on-out method. Journal of Hydrology 396: 24-32 DOI: 10.1016/j.jhydrol.2010.10.028
Mualem Y, Assouline S, Rohdenburg H. 1990. Rainfall induced soil seal (A) A critical review of observations and models. Catena 17 (2): 185-203

Mubarak I, Angulo-Jaramillo R, Mailhol JC, Ruelle P, Khaledian M, Vauclin M. 2010. Spatial analysis of soil surface hydraulic properties: Is infiltration method dependent? Agricultural Water Management 97 (10): 1517-1526 DOI: 10.1016/j.agwat.2010.05.005

Nunes AN, Lourenço L, Vieira A, Bento-Gonçalves A. 2016. Precipitation and erosivity in southern Portugal: seasonal variability and trends (1950-2008). Land Degradation \& Development 27 (2): 211-222 DOI: 10.1002/ldr.2265

Prosdocimi M, Jordán A, Tarolli P, Keesstra S, Novara A, Cerdà A. 2016. The immediate effectiveness of barley straw mulch in reducing soil erodibility and surface runoff generation in Mediterranean vineyards. Science of The Total Environment 547: 323-330 DOI: 10.1016/j.scitotenv.2015.12.076

Reynolds W. 1993. Unsaturated hydraulic conductivity, field measurement. Soil sampling and methods of analysis: 633-644

Reynolds W, Elrick D. 2002. Pressure infiltrometer. DANE, JH E TOPP, G.C. Methods of Soil Analysis, Part 4: 826-836

Reynolds WD, Bowman BT, Brunke RR, Drury CF, Tan CS. 2000. Comparison of tension infiltrometer, pressure infiltrometer, and soil core estimates of saturated hydraulic conductivity. Soil Science Society of America Journal $\quad 64 \quad$ (2): $\quad 478-484 \quad$ DOI: 10.2136/sssaj2000.642478x

Rockström J, Jansson PE, Barron J. 1998. Seasonal rainfall partitioning under runon and runoff conditions on sandy soil in Niger. On-farm measurements and water balance modelling. Journal of Hydrology 210 (1): 68-92

Shainberg I, Singer MJ. 1988. Drop impact energy-soil exchangeable sodium percentage interactions in seal formation. Soil Science Society of America Journal 52 (5): 1449 DOI: 10.2136/sssaj1988.03615995005200050046x

Shaver TM, Peterson GA, Ahuja LR, Westfall DG. 2013. Soil sorptivity enhancement with crop residue accumulation in semiarid dryland no-till agroecosystems. Geoderma 192: 254-258 DOI: 10.1016/j.geoderma.2012.08.014

Soil Survey Staff. 1998. Keys to Soil Taxonomy, 8th edn. Department of Agriculture, Natural Resources and Conservation Service: Washington, DC.

Somaratne NM, Smettem KRJ. 1993. Effect of cultivation and raindrop impact on the surface hydraulic properties of an Alfisol under wheat. Soil and Tillage Research 26 (2): 115-125 DOI: 10.1016/0167-1987(93)90038-Q

Souza ES, Antonino ACD, Heck RJ, Montenegro SMGL, Lima JRS, Sampaio EVSB, Angulo-Jaramillo R, Vauclin M. 2014. Effect of crusting on the physical and hydraulic properties of a soil cropped with Castor beans (Ricinus

Di Prima S, Bagarello V, Lassabatere L, Angulo-Jaramillo R, Bautista I, Burguet M, Cerdà A, Iovino M, Prosdocimi M. 2017. Comparing Beerkan infiltration tests with rainfall simulation experiments for hydraulic characterization of a sandy-loam soil. Hydrological Processes. DOI: 10.1002/hyp.11273 
communis L.) in the northeastern region of Brazil. Soil and Tillage Research 141: 55-61 DOI: 10.1016/j.still.2014.04.004

Tricker AS. 1979. The design of a portable rainfall simulator infiltrometer. Journal of Hydrology 41 (1-2): 143-147 DOI: 10.1016/0022-1694(79)90111-2

Turner RK, van den Bergh JCJM, Söderqvist T, Barendregt A, van der Straaten J, Maltby E, van Ierland EC. 2000. Ecological-economic analysis of wetlands: scientific integration for management and policy. Ecological Economics 35 (1): 7-23 DOI: 10.1016/S09218009(00)00164-6

van De Giesen NC, Stomph TJ, de Ridder N. 2000. Scale effects of Hortonian overland flow and rainfall-runoff dynamics in a West African catena landscape. Hydrological Processes 14 (1): 165-175 DOI: 10.1002/(SICI)1099-1085(200001)14:1<165::AIDHYP920>3.0.CO;2-1

Vandervaere J-P, Vauclin M, Haverkamp R, Peugeot C, Thony J-L, Gilfedder M. 1998. Prediction of crustinduced surface runoff with disc infiltrometer data. Soil science 163 (1): 9-21 DOI: 10.1097/00010694199801000-00003

White I, Sully MJ, Melville MD. 1989. Use and hydrological robustness of time-to-incipient-ponding. Soil Science Society of America Journal 53 (5): 13431346 DOI: $10.2136 /$ sssaj1989.03615995005300050007x
Xu X, Kiely G, Lewis C. 2009. Estimation and analysis of soil hydraulic properties through infiltration experiments: comparison of BEST and DL fitting methods. Soil Use and Management 25 (4): 354-361 DOI: 10.1111/j.1475-2743.2009.00218.x

Yilmaz D, Lassabatere L, Angulo-Jaramillo R, Deneele D, Legret M. 2010. Hydrodynamic Characterization of Basic Oxygen Furnace Slag through an Adapted BEST Method. Vadose Zone Journal 9 (1): 107 DOI: 10.2136/vzj2009.0039

Youngs E g. 1987. Estimating hydraulic conductivity values from ring infiltrometer measurements. Journal of Soil Science 38 (4): 623-632 DOI: 10.1111/j.13652389.1987.tb02159.x

Zimmermann A, Schinn DS, Francke T, Elsenbeer H, Zimmermann B. 2013. Uncovering patterns of nearsurface saturated hydraulic conductivity in an overland flow-controlled landscape. Geoderma 195-196: 1-11 DOI: 10.1016/j.geoderma.2012.11.002 